\title{
CHEMICAL CHARACTERISTICS OF SURFACE AND PHREATIC WATER AND THEIR EFFECTS ON THE GROWTH OF POPULUS EUPHARTICA OLIV. IN DESERT AREAS OF TARIM NATIONAL NATURE RESERVE, CHINA
}

\author{
YAN LIANG $^{1}$, LU-YING YANG ${ }^{2,3}$, AI-Di HuO ${ }^{* 2,3}$ AND WeN-Ke GUAN ${ }^{4}$ \\ School of highway, Chang'an University, Xi'an 710064, China \\ Keywords: Chemical characteristics, Growth of Populus euphratica, Rejuvenation, \\ The middle reaches of the Tarim River.
}

\begin{abstract}
Chemical characteristics of surface water and phreatic water and their relationship with the growth of Populus euphratica Oliv. were explored. In the study area, hydrochemical types of the surface water were mainly $\mathrm{S}^{\mathrm{CaIII}}$ or $\mathrm{Cl}^{\mathrm{NaIII}}$ (Based on the O. A. Arliekin's classification) and $\mathrm{PH}$ value of the surface water was below 8.0. The surface water from various sampling sites has a higher total hardness belonging to hard water and extremely hard water. The contents of sulfates and chlorides in the surface water in the protection zone ranged from 204.1 to $486.3 \mathrm{mg} / \mathrm{l}$ and from 70.9 to $239.9 \mathrm{mg} / \mathrm{l}$, respectively. Phreatic water is mainly recharged by the surface water infiltration. In terms of water quality, TDS, total hardness and total alkalinity of phreatic water at W2 sampling point were 17.3, 9.3 and 4.7 times of surface water, respectively. Populus euphratica was able to grow normally in the environment of brackish water, where total hardness, total alkalinity, and TDS of overflowing river were in the range of 325.3 769.5, 142.6 290.3 and 782.2 1037.5 mg/l, respectively. The Populus euphratica in juvenile phase was a few, and its rejuvenation was confronted with difficulty. The present study can provide a reference for exploring the water quality characteristics of surface and phreatic water and their relationship with the growth of Populus euphratica.
\end{abstract}

\section{Introduction}

As the most critical ecological factor in arid and desert areas, water is not only the basis and evidence for the composition, development, and stability of oasis ecosystem, but also determines the ecological evolution process of oasis and desertification (Chen et al. 2003). Populus euphratica is a representative tree species in oasis ecosystem, its renewal and reproduction are restricted by both water quantity and quality. Tarim Euphrates poplar national nature reserve is located in the middle reaches of Tarim River, which plays a great role in protecting animal and plant resources. However, the population size structure of Populus euphratica in this area is inverted pyramid. It is very dry in the Tarim basin. The harsh environment inhibited the germination and survival of the seedlings, and population maintenance was difficult (Wang et al. 2016).

Rivers in mountainous areas of Tarim Basin are mostly low-salinity bicarbonate water, which is mostly sulfate water in the middle of plain rivers (Wei 1994). The ions and salinity in the groundwater increase due to the rise of the groundwater level and strong evaporation near the river course of Tarim (Chen et al. 2005, Chen et al. 2006). The hydraulic relation between surface water and ground water is close (Huo et al. 2009a, Huo et al. 2009b, Huo et al. 2009c, Huo et al. 2011). After the construction of the water diversion embankment in the middle reaches of the Tarim River, the desalination belt along the river shrank in a large area, and the negative ecological effect began

*Author for correspondence: <huoaidi@163.com>. ${ }^{1}$ Key Laboratory of Education Ministry on Highway Engineering of Special Region, Chang'an University, Xi' an 710064, China. ${ }^{2}$ Key Laboratory of Subsurface Hydrology and Ecological Effects in Arid Region (Chang'an University), Ministry of Education, Xi'an 710054, China. ${ }^{3}$ School of Water and Environment, Chang'an University", Xi'an 710054, China. ${ }^{4}$ Afforestation Desert Control Research Institute, Xinjiang Academy of Forestry, Urumqi 830000, China 
to appear (Chen et al. 2009, Li et al. 2011). At present, the research focuses on hydrogeology and groundwater chemistry in the Tarim River basin, while the research on surface water and groundwater chemistry in the middle reaches and its influence on the growth of Euphrates poplar forest is less. According to the statistical data of the reserve in 2015, the woodland, open woodland and shrub woodland have decreased by $9.86,13.67$ and $15.05 \%$, respectively in 2006 , so the action to save Euphrates poplar forest is urgent.

Taking the Euphrates poplar nature reserve in Tarim as an example the chemical characteristics of surface water and groundwater in the middle reaches of the Tarim River were analyzed, so as to explore the influence of different surface water quality characteristics on the regeneration and succession of Euphrates poplar forests in desertification areas. It will provide theoretical support and scientific basis for the conservation, rejuvenation and regeneration of Euphrates poplar forests.

\section{Materials and Methods}

Study area is located in the middle of Tarim River (between Yingbaza in Luntai County and Qiala in Yuli County); and the river is about $398 \mathrm{~km}$ long. In the middle reaches of the Tarim River, it crosses the interlaced zone between the alluvial and diluvial plain at the southern foot of the Tianshan Mountains and the northern edge of the Taklamakan desert. The terrain is flat and deposited with silt. During flood season, the river water floods to form ponding swamps. The river channel is bend and often migrated to form a silt plain with a length of $100 \mathrm{~km}$ (Wang and Wang 2014). This region is crisscrossed by oases and deserts, and its ecological environment is fragile. From 2000 to 2013, the average annual vegetation coverage was $10.6 \sim 12.44 \%$, among which the vegetation coverage of farmland was increased significantly (Huo et al. 2011, Huo et al. 2019, Huo et al. 2020). Most of the upstream water was used by farmland, and ecological environment degradation was still the main tone (Guo and Huang 2016). Herbaceous plant is the main component of the plant community in this area, which are reeds, licorice, bougainvillea, and so on. There are still arbor species of Populus euphratica, gray leaf populus and shrubs of Tamarix, jingle thorn, black fruit medlar, etc. (Zhang and Liang 2016).

In September 25, 2016, scientific investigation was carried out in the Tarim Euphrates poplar national nature reserve during the flood season in Tarim River watershed. According to the different development of Euphrates poplar forests, surface water samples in ponded swamps were collected in flood overflow areas along the Tarim river trunk stream. The GPS system was used to locate and record the longitude, latitude and altitude of the sampling points. The sample sites were numbered as W1, W2 and W3. The W2 sampling point was excavated until the phreatic water was exposed, and the phreatic water sample was obtained. River samples were taken from the position of the Yuli bridge of the Tarim river trunk stream, and the sampling point was numbered W4. Three parallel samples were taken from each water body for water quality analysis and testing. In order to eliminate the influence of randomness, an average of all the rule results was calculated. Experiments were mainly carried out in the key laboratory of subsurface hydrology and ecological effects in arid region of ministry of education and key laboratory of education ministry on highway engineering of special region (Chang' an University, Xi'an, China).

$\mathrm{pH}$ was measured by acidity meter method; Total soluble solid was measured by quality standard method; Total alkalinity, carbonate ions and bicarbonate ions were measured by the method of the double indicator titration and sulfate-EDTA disodium volumetric method; Chloride was measured by method of silver nitrate; Ammonia Nitrogen was measured by Nessler reagent spectrophotometry method; Free carbon dioxide was measured by neutralization method; Calcium, magnesium ions and total alkalinity were measured EDTA disodium complexometric titration. 


\section{Results and Discussion}

The results of chemical analysis of water samples obtained from various sampling points in the research area are presented in Table 1. The results showed that the surface water from various sampling sites has a higher total hardness which belongs to hard water and extremely hard water.

Table 1. Water quality analysis in different sample plots (mg/l).

\begin{tabular}{|c|c|c|c|c|c|}
\hline \multirow[t]{2}{*}{ Items } & \multicolumn{5}{|c|}{ Sample location number } \\
\hline & W1 & W2 & W2 & W3 & W4 \\
\hline Water type & Surface water & Surface water & Aquifer water & Surface water & $\begin{array}{l}\text { Surface water } \\
\text { (Tarim river) }\end{array}$ \\
\hline $\mathrm{pH}$ value & 7.62 & 7.82 & 7.32 & 7.42 & 7.82 \\
\hline Total hardness $\left(\mathrm{CaCO}_{3}\right)$ & 369.1 & 325.3 & 3034.3 & 769.5 & 300.3 \\
\hline Total alkalinity $\left(\mathrm{CaCO}_{3}\right)$ & 165.2 & 142.6 & 665.7 & 290.3 & 115.1 \\
\hline Total dissolved solids & 782.2 & 838.0 & 14476.3 & 1037.5 & 615.3 \\
\hline Sulfate & 252.2 & 216.1 & 3452.2 & 486.3 & 204.1 \\
\hline Chloride & 164.0 & 239.9 & 5340.7 & 70.9 & 133.0 \\
\hline Calcium & 77.7 & 67.6 & 438.4 & 132.8 & 70.1 \\
\hline Magnesium & 42.5 & 38.0 & 471.0 & 106.4 & 30.4 \\
\hline $\begin{array}{l}\text { Ammonia nitrogen } \\
\left(\mathrm{NH}_{4}{ }^{-}-\mathrm{N}\right)\end{array}$ & 0.20 & 0 & 0 & 0.45 & 0 \\
\hline Bicarbonate root & 201.4 & 173.9 & 799.4 & 353.9 & 140.3 \\
\hline Carbonic acid root & 0 & 0 & 0 & 0 & 0 \\
\hline Free $\mathrm{CO}_{2}$ & 16.5 & 6.6 & 69.3 & 27.5 & 4.4 \\
\hline
\end{tabular}

Sampling time was during the high flow season of Tarim River. The main and overflowing river water in the reserve were fresh and brackish water. The TDS of the water sample in the position of the Yuli bridge in the middle reaches of the Tarim River main stream was $615.3 \mathrm{mg} / \mathrm{l}$. According to the hygienic standard of drinking water (GB5749 - 2006), the dissolved solid less than $1000 \mathrm{mg} / \mathrm{l}$ can be considered as fresh water. The surface water salinity of W2 sampling point was $838 \mathrm{mg} / \mathrm{l}$. At the digging depth of $65 \mathrm{~cm}$ under the Euphrates poplar forest was in the W2 sample plot, the water was exposed, whose salinity reached $14.5 \mathrm{~g} / \mathrm{l}$, belonging to the brine $(10-50 \mathrm{~g} / \mathrm{l})$. This indicated that the surface salinity was strong. The TDS of surface water samples in W3 was $1037.5 \mathrm{mg} / \mathrm{l}$, being brackish water. TDS in W3 water sample was $68.6 \%$ higher than that in W4 water sample.

The $\mathrm{pH}$ value of surface water and phreatic water sample was between 7.32 and 7.82. The water sample of Tarim main stream in the position of Yuli Bridge had the highest $\mathrm{pH}$ value (7.82) and the $\mathrm{pH}$ value at $\mathrm{W} 2$ sampling point was the lowest (7.32). The total alkalinity $\left(\mathrm{CaCO}_{3}\right)$ of surface water samples in various places was between 100 and $300 \mathrm{mg} / \mathrm{l}$. Compared with other surface water samples, the total alkalinity of water samples at W4 sampling point in the Tarim River trunk stream was the lowest $(115.1 \mathrm{mg} / \mathrm{l})$. The water quality of Tarim main stream is better than the overflow river water on both sides of the river in terms of salinity and total hardness (Table 1). This might be due to (a) Water evaporation causes salt enrichment in the surface of both sides of the river, (b) The slow water flow and strong evaporation in the ponding marsh also worsen the water quality, (c) In the main channel, the water supply is relative large and the river water is moving, so the salt in the water is not easy to deposit. 
Phreatic water is mainly recharged by the surface water infiltration. In terms of water quality, TDS, total hardness and total alkalinity of phreatic water at W2 sampling point were 17.3, 9.3 and 4.7 times of surface water, respectively. This is because phreatic water dissolves more salts in the soil. The water quality is closely related to the soil environment, which reflects the degree of soil salinity.

The contents of sulfates and chlorides in the surface water in the protection zone ranged from 204.1 to $486.3 \mathrm{mg} / \mathrm{l}$ and from 70.9 to $239.9 \mathrm{mg} / \mathrm{l}$, respectively. The chloride content of $133 \mathrm{mg} / \mathrm{l}$ and the sulfate content of $204.1 \mathrm{mg} / \mathrm{l}$ in the river water samples in the position of Yuli bridge of Tarim River are both lower than the corresponding limits in the national drinking water quality and sanitation standards $(250 \mathrm{mg} / \mathrm{l})$. The sulfate content of surface water at the sampling point W3 was $486.3 \mathrm{mg} / \mathrm{l}$. This surface water belongs to brackish water. In the surface waters of W1 and W3 sample plots, the ammonia nitrogen content exceeds the national nature reserve Class I standard $(\leq 0.15 \mathrm{mg} / \mathrm{l})$ according to the surface water environmental quality standard (GB3838-2002). Correspondingly, the free $\mathrm{CO}_{2}$ content in water of $\mathrm{W} 1$ and $\mathrm{W} 3$ sample plots was relatively high which were, 16.5 and $27.5 \mathrm{mg} / \mathrm{l}$, respectively. Large areas of cash crops such as cotton, oil palm, red medlar and melon are planted in the study area, indicating that the surface water in the middle reaches of the Tarim River has been affected by human factors such as agricultural drainage. In conclusion, TDS, total alkalinity and total hardness in the middle reaches of the Tarim River increased in different degrees because the overflowed river water flowed through the surface with serious salt accumulation, and the salt index in the phreatic aquifer was much higher than the surface water in the same area. At the same time, large-scale reclamation on both sides of the river has also had a negative impact on water quality in the middle reaches of the Tarim River.

In the early autumn of 2016, the Euphrates poplar in the desert riparian forest in the middle reaches of the Tarim River had entered the deciduous stage and its leaves began to turn yellow. According to vegetation type, quantity and overall coverage, the habitats of Populus euphratica forest community are divided into three regional types: desertification area, transition zone and riverbank radiation area. The results of field investigation showed that the population size of Populus euphratica and Populus pruinosa in this area are inverted pyramid with few young individuals and little renewal resources. The growth characteristics of Populus Euphrates in W1, W2 and W3 plots are shown in Table 2.

Table 2. Growth characteristics of Populus euphratica in 3 chosen plots.

\begin{tabular}{|c|c|c|c|}
\hline \multirow[t]{2}{*}{ Item } & \multicolumn{3}{|c|}{ Sample number } \\
\hline & W1 & W2 & W3 \\
\hline Growth pattern & $\begin{array}{l}\text { Populus } \\
\text { euphratica-Tamarix } \\
\text { chinensis }\end{array}$ & $\begin{array}{l}\text { Populus } \\
\text { euphratica-Tamarix } \\
\text { chinensis-reed }\end{array}$ & Populus euphratica \\
\hline $\begin{array}{l}\text { Main } \\
\text { species }\end{array}$ & $\begin{array}{l}\text { Tamarix chinensis } \\
\text { (dominant species), } \\
\text { Populus euphratica }\end{array}$ & $\begin{array}{l}\text { Populus Euphrates, } \\
\text { tamarisk, Tamarisk, reed, } \\
\text { Camel thorn, salt grass }\end{array}$ & $\begin{array}{l}\text { Populus euphratica, Tamarix } \\
\text { chinensis }\end{array}$ \\
\hline Total coverage & $30 \sim 60 \%$ & $80 \sim 100 \%$ & $80 \sim 100 \%$ \\
\hline Breeding way & Root rice breeding & Seeds, root rice breeding & Seeds, root rice breeding \\
\hline
\end{tabular}

W1 sample plot is located in the terraces on the south bank of the Tarim River, which is a transitional zone with a surface layer of salt crystallization. It is affected by seasonal floods and has a short submergence period. The dominant species is Tamarix chinensis, growing in bunches with 
the height of 2 4 $\mathrm{m}$ and the diameter of $2 \sim 6 \mathrm{~m}$, and the height of the sand fixation of $20 \sim 40 \mathrm{~cm}$ near surface. Populus euphratica grows sparsely.

W2 sample plot is a riparian radiation area, where rivers flow through during the flood season. The population structure of Populus euphratica is relatively stable in this area. The age of trees is mostly in the middle age and near mature stage. The height of the main Populus euphratica is $7 \sim 10$ $\mathrm{m}$, with more than 170 trees per hectare. The height of the topmost tree is more than $16 \mathrm{~m}$ and the height of the young tree layer is $3 \sim 5 \mathrm{~m}$, and the number of young trees per hectare is about 320 . Tamarix chinensis is distributed in clumps or patches, with a height of $2 \sim 4 \mathrm{~m}$ and a coverage rate of $10 \sim 30 \%$. Grass species are reed, salt grass, camel thorn and so on. The TDS value of groundwater in the W2 sample was $14.5 \mathrm{~g} / \mathrm{l}$. The groundwater contains $10 \sim 20 \mathrm{~g} / \mathrm{l}$ of dry matter and only the most salt-tolerant tree species can adapt (Huo et al. 2009c, Huo et al. 2016, Wang et al. 2016). Therefore, the vegetation of riparian forest in this area is mainly middle-aged and old-aged Populus euphratica and salt-tolerant shrubs.

W3 sample plot is located in the flood plain with patches of Populus euphratica forest and few grasses, and the renewal and succession of Populus euphratica is relatively easy. The seedlings and root-sucker seedlings of Populus euphratica, $15 \sim 30 \mathrm{~cm}$ high, can be seen on the new alluvium.. Populus euphratica saplings are generally within 10 years old, with a height of $2 \sim 4 \mathrm{~m}$, and about $20 \sim 40$ trees per $100 \mathrm{~m}^{2}$ area. The saplings have started to differentiate, with a large number of apoptosis and being natural sparse. The associated species of $P$. euphratica community is unstable and the main species is Tamarix chinensis.

The results showed that the surface water chemical characteristics changed little and the water quality was stable in the three different growth modes of Euphrates poplar forest, which was basically suitable for the growth of Euphrates poplar forest.

The total hardness, alkalinity and TDS of the overflowing river are higher than those of the main stream. The surface water in the study area is adversely affected by farmland drainage, and the ammonia nitrogen content was $0-0.45 \mathrm{mg} / \mathrm{l}$. The surface water in some areas is already brackish water. Overall, the water quality has little difference. Populus euphratica can grow normally in brackish water with TDS $>1000 \mathrm{mg} / \mathrm{l}$. The vegetation in the study area is mainly composed of xerophytes and halophytes, which are suitable for Populus euphratica growing in sandy soil. The Populus euphratica and Populus pruinosa in this area had fewer young individuals and lacked regeneration resources, which is a declining species. The harsh environment in the Tarim River basin inhibited the germination and survival of Populus euphratica seedlings.

\section{Acknowledgements}

This work was supported by the National Natural Science Foundation of China (Grants No. 41790444 and 41877232). Key R \& D projects of Shaanxi Province (Grants No. 2020SF-424); Key Laboratory Open Project Fund of State Key Laboratory of Loess and Quaternary Geology, Institute of Earth Environment, CAS (Grants No. SKLLQG1909). Natural Science Foundation of Ning Xia (Grants No. 2020AAC03476 and 2021AAC03429); the Public Welfare Project of Ningbo City (Grants No. 202002N3139 and 2019C10051). This work was also supported by "Research and

demonstration on restoration of Populus euphratica forest in Tarim River (2017-HY)". We would like to thank the reviewers and editors for their constructive comments, which helped to significantly improve the manuscript.

\section{References}

Chen Y, Li W and Xu H 2003. Effects of groundwater level on vegetation in the lower reaches of Tarim river. Acta Geologica Sinica 58(4): 542-549. 
Chen Y, Chen Y and Li W 2005. Groundwater quality change and Euphrates poplar forest regeneration under water transfer - a case study of the YingSu section of the lower reaches of Tarim river. Arid area research 22(1): 101-105.

Chen YN, Wang Q, Li WH, Ruan X, Chen YP and Zhang LH 2006. Study on the rational groundwater level characterized by vegetation physiological and ecological data: A case study of ecological restoration process in the lower reaches of Tarim River. Chinese Sci. Bull. (S1): 7-13.

Chen YJ, Chen YN and Liu JZ 2009. Variations in groundwater chemistry and the movement of salt infuenced by the dikes in the wetlands of middle reaches of Tarim river. J. Liaocheng University (Natural Science Edition) 22(4): 79-85.

Guo H and Huang Y 2016. Vegetation cover dynamics of Tarim river trunk stream based on multi-scale remote sensing data. China Desert 36(5):1472-1480.

Huo A, Sun Z, Li H, Hou X and Zhang G 2009a. Study on the monitoring model of soil moisture for Aeolian desertification using MODIS image data. Proc Spie 7840: 78400D-78400D-78407.

Huo A, Wang G and Zhang J 2009b. Research on Retrieving Aeolian Desertification Land Surface Temperature of North Shaanxi Province with MODIS Data. In: Fifth International Conference on Natural Computation 6: $243-248$.

Huo A, Kang XW, Liu ZL and Cao XS 2009c. Simplified Split-window Algorithm Model to Retrieve Land Surface Temperature in Aeolian Desertification Area with MODIS Image Data - Taking North Shaanxi Province as an Example. J. Earth Sci. Environ. 31(3): 306-311.

Huo A, Xie J, Sun Z and Zhou L 2011. Methodology of land surface broadband albedo retrieval in the desertification area based on MODIS image data. In: International Symposium on Water Resource \& Environmental Protection: 115-118

Huo A, Dang J, Song JX, Chen XH and Mao HR 2016. Simulation modeling for water governance in basins based on surface water and groundwater. Agricul. Water Manage.174: 22-29.

Huo A., Wang X, Liang Y, Jiang C and Zheng X 2019. Integrated numerical model for irrigated area water resources management. J. Water and Climate Change. https://doiorg/102166/wcc2019042.

Huo, A, Yang L, Peng J, Cheng Y and Jiang C 2020. Spatial characteristics of the rainfall induced landslides in the Chinese Loess Plateau, Human and Ecological Risk Assessment: An Int. J. DOI: 10.1080/ 10807039.2020.1728517.

Li W, Chen Y, Zhang B and Liu J 2011. Chemical changes of groundwater in the middle reaches of Tarim river and its influencing factors. Environ. Chem. 30(2): 459-465.

Wang L and Wang X 2014. Comparative study on main physical and chemical properties of typical soil samples in the middle reaches of Tarim river. Northern Horticul. 1(23):148-151.

Wang L, Luo L, and Liu P 2016. Effects of water disturbance in the middle and lower reaches of tarim river on species diversity of populus Euphrates. Arid Region Geogr. (Chinese Version) 39(6):1275-1281.

Wei Z 1994. Characteristics of surface water chemistry in Tarim basin and its changes under the influence of human activities. Resou. Environ. Arid Areas 1(2): 23-30.

Zhang $\mathrm{H}$ and Liang $\mathrm{J}$ 2016. Relationship between distribution characteristics of soil physical and chemical properties and vegetation in desert riparian forests in the middle reaches of Tarim river. Soil Water Conserv. Res. 23(2): 6-12.

(Manuscript received on 19 May, 2021; revised on 20 August, 2021) 